\title{
Identifying influence of perceived quality and satisfaction on the utilization status of the community clinic services; Bangladesh context
}

\author{
Karim RM ${ }^{1}$, Abdullah $\mathrm{MS}^{2}$, Rahman $\mathrm{AM}^{3}$, Alam $\mathrm{AM}^{4}$ \\ 1.Department of Community Medicine, Abdul Malek Ukil Medical College, Begumgonj, Noakhali, 2. Filaria \\ Control Program, CDC, Directorate General of Health Services, Mohakhali, Dhaka, 3. Department of \\ Epidemiology, National Institute of Preventive and Social Medicine, Mohakhali, Dhaka, 4. Department of \\ Maternal and Child Health, National Institute of Preventive and Social Medicine, Mohakhali, Dhaka. \\ Email: shameem.m25@gmail.com
}

\begin{abstract}
Background: Bangladesh is one among the few countries of the world that provides free medical services at the community level through various public health facilities. It is now evident that, clients' perceived quality of services and their expectations of service standards affect health service utilization to a great extent. The aim of the study was to develop and validate the measures for perception and satisfaction of primary health care quality in Bangladesh context and to identify their aspects on the utilization status of the Community Clinic (CC) services. Methods: This mixed method cross sectional survey was conducted from January to June 2012, in the catchment area of 12 Community Clinics (CCs). Since most of the outcome indicators focus mainly on women and children, women having children less than two years of age were randomly assigned and interviewed for the study purpose. Data for the development of perceived service quality and satisfaction tools were collected through Focus Group Discussion (FGD), key informants interview and data for measuring the utilization status were collected by an interviewer administered pretested semi-structured questionnaire. Results: About 95\% of the respondents were Muslims and 5\% were Hindus. The average age of the respondents was 23.38 ( $\mathrm{SD} \pm 4.15)$ years and almost all of them are home makers. The average monthly expenditure of their family was 7462.92 ( $\mathrm{SD} \pm 2545$ ) BDT equivalent to 95 ( $\mathrm{SD} \pm 32$ ) US\$. To measure lay peoples' perception and satisfaction regarding primary health care service quality two scales e.g. Slim Haddad's 20-item scale for measuring perceived quality of primary health care services (PQPCS) validated in Guinea and Burkina Fuso and primary care satisfaction survey for women (PCSSW) developed by Scholle and colleagues 2004; is a 24-item survey tool validated in Turkey were chosen as a reference tools. Based on those, two psychometric research instruments; 24 items PQPCS scale (chronbach's $\alpha=0.89$ ) and 22-items Community Clinic Service Satisfaction (CCSS) scale (chronbach's $\alpha=0.97$ ), were constructed and validated for measuring perceived service quality and satisfaction in Bangladesh context. This study showed mothers with pre-primary education $[(\chi 2=4.20, \mathrm{p}=0.04)$, AOR with $95 \%$ $\mathrm{CI}=1.89(1.03,3.53)]$ utilized the limited curative care services more than educated mothers. On the contrary, higher income families [for income group 5000-10,000 BDT $\chi 2=8.83, \mathrm{p}=0.003$ and AOR with $95 \% \mathrm{CI}=0.37(0.19,0.71)$ ] and [for income group above $10,000 \mathrm{BDT} \chi 2=5.02, \mathrm{p}=0.025$ and AOR with $95 \% \mathrm{CI}=0.40(0.18,0.89)]$ and families having cultivable lands [for 5-10 decimal group $\chi 2=5.51, \mathrm{p}=0.19$, and AOR with $95 \% \mathrm{CI}=0.56(0.35,0.91)]$ and [for $>10$ decimal group $\chi 2=6.70$, $\mathrm{p}=0.010$, and AOR with $95 \% \mathrm{CI}=0.50(0.29,0.84)]$ utilized the limited curative care services less than their poorer and landless counterpart. The same relationship was observed in case of health education and Antenatal Care (ANC) and Postnatal Care (PNC) services. Women who lived in their own residence used health education services more frequently than those who lived in a rental house $[\chi 2$ $=24.00, \mathrm{p}=0.000$ and $\mathrm{AOR}$ with $95 \% \mathrm{CI}=1.21,(1.12,1.30)]$ and they also increasingly used maternal and child health services $\chi^{2}=27.49, \mathrm{p}=0.000$ and AOR with $95 \%$ CI 1.61, $\left.(1.35,1.93)\right]$. Perceptions concerning skill and competence of the health care provider $[\chi 2=16.90, p=0.000$ and AOR with $95 \%$ $\mathrm{CI}=1.14,(1.07,1.22)]$ and satisfaction indicating interpersonal communication and attitude of the care provider $[\chi 2=7.07, \mathrm{p}=0.008$ and $\mathrm{AOR}$ with $95 \% \mathrm{CI}=1.08,(1.02,1.15)]$ were found significant predictors for limited curative care service utilization of CC. Perception related to the quality of management, administration, physical environment of the service point and satisfaction addressing health promotion and women health issues also played significant role on CC's services utilization. Conclusions: Besides parental education and income, client's perception and satisfaction played significant role in CC service utilization. Provider's perception of service quality should be studied. The study findings will enable policy-makers to improve quality of primary health care services, realizing providers' and patients' ideas of CC service quality.
\end{abstract}




\section{Introduction}

Bangladesh government has revitalized the CC project as a commitment of delivering free primary health care services at the doorstep of rural people and until now 12,527 independent CCs have been made functional to deliver basic healthcare package to the community people, viz. maternal and child healthcare, reproductive health and family planning services, immunization, nutrition education, micronutrient supplementation, health education and counselling, communicable disease control, treatment for minor ailments and first-aid, and referral to higher-level health centres. ${ }^{1} \mathrm{CCs}$ were to provide services for around 6000 people, and it was envisaged that their location would make them accessible for $80 \%$ of the population within less than 30 minutes walking distance. ${ }^{2}$ These CCs were to bring family planning, preventive health services and limited curative services closer to the population, and to improve the efficiency of service provision, partly by replacing outreach services with services provided from a fixed point. Health Population Nutrition Sector Development Program (HPNSDP) has given much emphasis for its development and sustainability. It is now evident that services empathetically embrace the community accessibility and affordability issues let alone quality do not ensure its utilization and sustainability. ${ }^{3-6}$ Experiences in Bangladesh ${ }^{7}$ and also in $\mathrm{China}^{8}, \mathrm{Nepal}^{9}$ and other countries provide growing evidence that the perceived quality of health care service has a strong impact on utilization patterns. The low utilization of both community health workers and first line health services is, to a large extent, due to consumers' dissatisfaction and perceptions of low quality of care. ${ }^{10-17}$

Satisfaction reflects the extent to which expectation of service standards have been met while perception of quality record patient rating about specific aspects of service quality. ${ }^{18-20}$ The quality of care concept has been well-thought-out as a social phenomenon that vary across policy makers, professionals, managers, social workers, common users. This concept is also related to the type of care provided as well as to the social, physical and technical context in which the care is delivered. ${ }^{21}$ As user's viewpoints regarding service quality offers the potential to make services more responsive to people's expectations, making health services better utilized, variety of approaches were attempted for a valid assessment of quality.

Public health researchers have developed a number of scales for measuring user's perception and satisfaction with general practitioner services, where they identified different dimensions of primary care such as: access, office staff, privacy, waiting time, user's own expectations, the competence and personal characteristics of the physician, empathy, listening, respect, provider skills, care coordination and environment. Andaleep et al. compared several dimensions of perceived quality of care e.g. responsiveness, assurance, communication, discipline and "baksheesh"; unofficial payments, between public hospitals with private hospitals in Dhaka city and argued that these factors have a relatively greater influence on individuals' decisions regarding utilization compared with access and costs. Haddad et al. developed and validated a 20 item scale in Guinea which is claimed to be an appropriate one for measuring lay peoples' perception in a similar setting. Some of the studies use qualitative approaches with open interviews, while others use quantitative approaches based on structured questionnaires.

These measures differ in their dimensions, the number of items, the response formats, as well as the rules used to construct the global scores and some of the measures do not, however, provide sufficient methodological explanation. ${ }^{22-27}$ Previous assessments of client satisfaction with services provided by government health workers in Bangladesh have mostly been limited to family planning services.

Health-care researchers who work with culturally diverse communities stated the importance that the measurement of quality related to primary health care services and satisfaction may vary in different cultural settings. ${ }^{26}$ Bangladeshi cultural values may influence the measurement of service quality and primary care satisfaction; this study was conducted to determine whether the proposed scale structure of the primary care perception and satisfaction in its present form taps into these culturally salient values, and thus whether it is appropriate for use with Bangladeshi rural community. ${ }^{27}$

The first objective of this study is to develop instruments to measure community perception and satisfaction regarding primary health service quality in Bangladesh and evaluate their reliability and validity. The second objective is to identify aspects of perceived quality and satisfaction which have large effects on the utilization status of the $\mathrm{CC}$ services.

\section{Materials and Methods}

Sampling: This mixed method cross sectional survey was conducted from January to June 2012 in the catchment area of $12 \mathrm{CCs}$, located at six districts. The respondents were enrolled following 
simple random sampling technique. Previous study showed $68.9 \%$ patients expressed satisfaction with the provider's usual behaviour in primary healthcare settings of Bangladesh. ${ }^{28}$ Assuming $\mathrm{p}=0.689,95 \%$ confidence interval, $80 \%$ power, $3 \%$ margin of error, the estimated sample size was 915 . The sample was further increased by $5 \%$ to account for contingencies such as non-response or recording error, with a final figure of 960.

\section{Bangladesh [Total 64 Districts] \\ $\downarrow$ Random selection of 6 districts \\ 6 Districts \\ $\downarrow$ Random selection of one upazila from one district}

6 Upazilas (Upazilas are basic unit of administration of the country. Upazilas are similar to the county subdivisions found in some western countries. Total no of upazilas are 509.)

$\downarrow$ Random selection of one union from each Upazila

6 Unions (Union Councils are the smallest rural administrative and local government units in Bangladesh. Each Union is made up of nine Wards. There are 4,550 Unions in Bangladesh.)

$\downarrow$ Random selection of two wards from each union

12 Wards (a village or ward is the smallest territorial and social unit for administrative and representative purposes. At the 1991 census, villages in Bangladesh had an average of 232 households.)

Random selection of eighty mothers having children 1 less than two years of age from each ward 960 respondents

Firstly, six districts were chosen by lottery, from which six upazilas (Sundargonj, Baliadangi, Ullapara, Sherpur, Sreepur and Chakaria) were selected randomly. Random allocation of one union from each upazila, and two wards from each union, yielded 12 wards (each ward comprises approx. 6000 population). From each ward, 80 eligible mothers (Mothers having children less than two years of age and one mother from each household) were randomly assigned and interviewed for the study purpose. Since most of the rural males seldom stay at home during day time and most of the important outcome indicators focus mainly on women and children health, researcher deliberately enrolled women respondents for the study purpose.

After a five years' closure, CCs were re-opened for the last two and half years and for this reason, it was logical to select mothers from those households having children aged less than two years, to investigate the utilization of selected health care services among them. Data were collected by six trained data collectors through face to face interview at the household level using interviewer administered semi-structured questionnaire. To cross check the information provided by the respondents regarding $\mathrm{CC}$ services related to the children and mother, relevant documents were also reviewed (Vaccination card, Pregnancy Card, Prescriptions, etc). Informed consents were taken before interviewing the respondents. Ethical clearance was obtained from ethical review board of Bangladesh Medical Research Council.

Method of developing scale and subscales for measuring perceived service quality

An exploratory study was conducted at the first phase to develop and evaluate the properties of two new scales for measuring perceived quality and satisfaction related to primary health care services in Bangladesh. Slim Haddad's 20-item scale for measuring perceived quality of primary health care services that includes three subscales related to health care delivery, personnel and facilities has been tested and validated in Guinea and Burkina Fuso. Researcher chose this measure as reference for developing a new tool. ${ }^{16,18}$ We conducted 12 homogenous focus group discussions (stratified by sex and age), 24 key informants interview of local people from six CCs areas adjacent to the selected study areas to identify the criteria they use to judge the quality of service at CC. Their statements were recorded, translated into English, and transcribed under the supervision of experienced researchers. Comments and concepts revealing respondents' views on quality were extracted. At the same time, different studies on patient's perception of quality were meticulously reviewed to explore further scale items. ${ }^{12,16,18-20}$ Some of the attributes were found common in both processes e.g. qualitative data extraction and literature review, such as; health provider's skill in detecting health problem, quality of drugs supplied, treatment outcome, prescription quality, monitoring (late open and early closure, favouring relatives), equipment (necessary for clinical examination and primary laboratory examinations), availability of staffs, adequacy of the examination area, personal characteristic of the health worker (sympathetic, respectful, open hearted and honest), time given for explaining their illness and distance from their residence. Some attributes, e.g. what extent they can examine (female patient), counselling skill, information regarding tests and procedures, confidentiality, hurriedness of the health workers while attending clients, punctuality, bribe, hassle in collecting drugs and the physical environment (external environment, water supply, toilet facilities) were newly extracted. Results from both efforts led to an initial list of 30 quality attributes addressing skill and competence of the health care provider, management, administration and physical arrangement of CC.

In the second phase, a survey was undertaken to prioritize these criteria according to the degree of importance the users ascribe to them when judging quality of care. Sixty randomly selected 
respondents; 10 from each ward of six selected unions were recruited for this purpose. The questionnaire was produced in the third phase. It was drafted simultaneously in English and Bengali, following a process of back translation. The back translation process was completed with the collaboration of "Health education and behavioural science" and "Community medicine" departments of National Institute of Preventive and Social Medicine (NIPSOM). The face validity of the questionnaire was openly assessed through feedback from a panel of experts (researchers, managers of CC revitalization program, specialists from Management Information System (MIS), Directorate General of Health Services (DGHS) and faculties of NIPSOM) who reviewed the questionnaire and confirmed it with minor wording changes. Content validity was revealed by asking experts to review the adequacy of the content of the instrument. They were asked to rate the clarity, the concreteness, the centrality, and the importance of each item. Inter-rater agreement was analysed for every item to value their adequacy.

The questionnaire was then pretested on 24 people of the adjacent communities of the selected areas to allow for adjustment of wording. Each question refers to one of the 30 attributes identified in the previous phase. For each question, respondents could express one of four opinions: do not know (0), not good (1), average (2), or good (3). The scoring system differs with that of Haddad et al. as we scored "do not know"=0 and "not good"=1 assuming the fact that those who never took any of the CC services, should have lower score than those who at least went to $\mathrm{CC}$ for some purpose though their perception regarding those services was not favourable.

Method of developing scales and subscales for measuring satisfaction

The CC Service Satisfaction scale was developed complying with the same basic principles as followed in constructing PQPCS scale. The PCSSW developed by Scholle and colleagues 2004; is a 24-item survey tool consisting of three subscales that have been shown to be psychometrically valid among Turkish women was chosen as a reference tool for the purpose. ${ }^{26}$ Each PCSSW item is rated on a 5-point scale: $1=$ not at all satisfied; 2=somewhat satisfied; 3=satisfied; $4=$ very satisfied; and 5=extremely satisfied. As no study found to be focused specifically on PCSSW, there might be reason to believe that the measurement of the primary care satisfaction may differ in different cultural context. Therefore, the study planned to validate the scale items of PCSSW to make it representative of the constructs of CCSS scale from Bangladesh perspective and to customise it as culturally sensitive.

\section{Measuring utilization status of the CC services}

$\mathrm{CC}$ services are multifaceted and inter-related and the clinics provide services, operationally termed as essential service package (ESP) that includes of services related to reproductive health, child health, behaviour change communication, communicable disease control, and limited curative care, off which researcher preferred five of the most important amenities; "treatment for general illness or limited curative care", health education, maternal and child health, antenatal and postnatal care" as outcome indicators for evaluating their utilization status.

Statistical analysis: The data was entered, cleaned and edited with the help of Software "Statistical Package for the Social Sciences" (SPSS) for windows version 20.0. After describing the data, chi-square and Student's t test were performed to determine the association between sociodemographic characteristics, PQPCS, CCSS and utilization of CC services. Finally, to predict the role of perceived service quality and satisfaction of service utilization, while controlling for possible confounders, those variables showed $p<0.20$ in univariate analysis, were included in binary logistic regression models. Adjusted Odds ratios (AOR), $95 \%$ confidence intervals $(95 \% \mathrm{CI})$ and p-values were calculated for each potential contributors. Cox and Snell and Negelkerke $\mathrm{R}^{2}$ referring the explained variability and ROC values with $95 \%$ CIs indicating case classification status of the model were also reported.

\section{Results}

Construction of scales and subscales for measuring perceived quality

Factor analysis [Table I]

The 30 items of PQPCS measure were subjected to principal components analysis (PCA) using SPSS Version 20. Prior to performing PCA the suitability of data for factor analysis was assessed. Inspection of the correlation matrix revealed the presence of many coefficients of 0.3 and above. The KaiserMeyer-Oklin value was 0.89 , exceeding the recommended value of 0.6 (Kaiser, 1970, 1974) and the Barlett's Test of Sphericity (Bartlett, 1954) reached statistical significance, supporting the factorability of the correlation matrix. Principal components analysis revealed the presence of four components with eigenvalues exceeding one, explaining 30.9 percent, 15.3 percent, 7.8 percent and 6.8 percent of the variance respectively. An inspection of the scree plot revealed a clear break 
after the fourth component. Using Catell's (1966) scree test, it was decided to retain four components for further investigation. This was further supported by the results of Parallel Analysis, which showed only four components with eigenvalues exceeding the corresponding criterion values for a randomly generated data matrix of the same size (30 variables $\times 960$ respondents).

TableI: Factor analysis for perceived quality of primary health care PQPCS

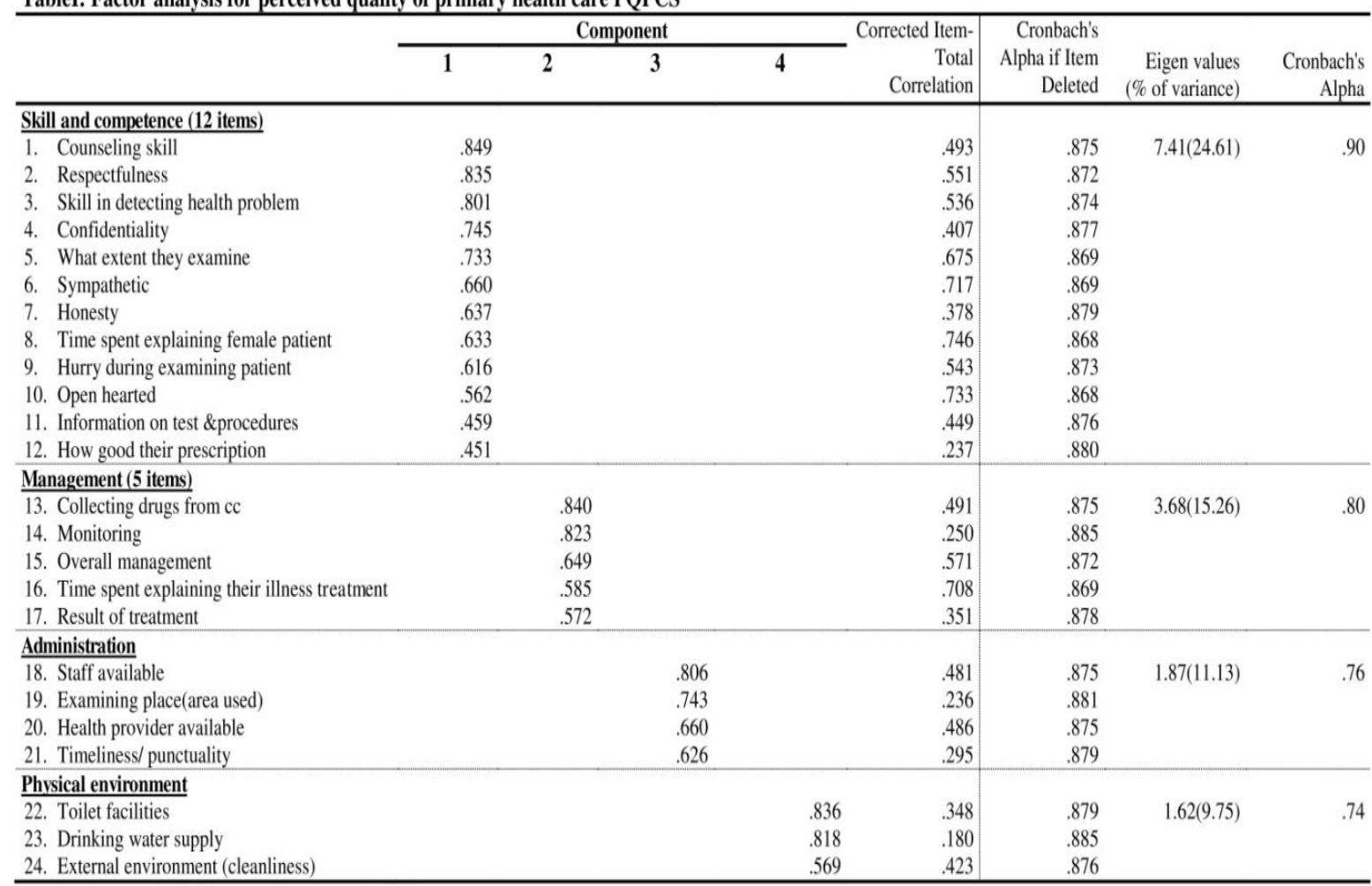

Total variance $=60.74 ;$ Cronbach's Alpha $=.89(24$ items $)$

TableII: Factor analysis for community clinic service satisfaction CCSS

\begin{tabular}{|c|c|c|c|c|c|c|}
\hline & \multicolumn{3}{|c|}{ Component } & \multirow{2}{*}{$\begin{array}{r}\text { Corrected } \\
\text { Item-Total } \\
\text { Correlation }\end{array}$} & \multirow{2}{*}{$\begin{array}{r}\text { Eigen value } \\
\text { Variance) }\end{array}$} & \multirow{2}{*}{$\begin{array}{r}\text { Cronbach's } \\
\text { Alpha }\end{array}$} \\
\hline & 1 & 2 & 3 & & & \\
\hline \multicolumn{7}{|l|}{ interpersonal skill and attitude of the care provider } \\
\hline 1. The amount of time I had to talk with my health professional & .814 & & & .740 & $12.9(32.94)$ & .95 \\
\hline 2. The staff 's flexibility in scheduling my appointment around my needs & .802 & & & .791 & & \\
\hline 3. The courtesy of the staff & .797 & & & .730 & & \\
\hline 4. My health professional's ability to answer questions in a sensitive and caring way & .783 & & & .816 & & \\
\hline 5. My health professional's ability to help me feel comfortable talking about my concerns & .768 & & & .847 & & \\
\hline 6. The chance to ask all of my questions & .762 & & & .806 & & \\
\hline 7. My overall trust in the health professionals here & .715 & & & .716 & & \\
\hline 8. Privacy when talking to the receptionist & .706 & & & .676 & & \\
\hline 9. My health professional's ability to take what I say seriously & .663 & & & .836 & & \\
\hline 10. My health professional's willingness to explain different options for my care & .607 & & & .819 & & \\
\hline 11. How well the staff kept you informed about the waiting time & .448 & & & .605 & & \\
\hline \multicolumn{7}{|l|}{ preventive and promotive health services } \\
\hline 12. How well the health professionals explain the results of tests or procedures & & .813 & &. .722 & $1.7(23.25)$ & .92 \\
\hline 13. Information about how to get the results of my tests & & .791 & & .765 & & \\
\hline 14. The health professionals' focus on prevention & & .684 & & .468 & & \\
\hline 15. How well my health care fits my stage of life & & .684 & & .775 & & \\
\hline 16. The health professionals' interest in my mental and emotional health & & .666 & & .774 & & \\
\hline 17. The information I get about healthy living. (such as diet and exercise & & .630 & & .776 & & \\
\hline 18. My health professional's interest in how my life affects my health & & .622 & & .787 & & \\
\hline \multicolumn{7}{|l|}{ women health issue } \\
\hline 19. The health professionals' knowledge of women's health issues & & & .819 & .664 & 1.1(14.97) & .86 \\
\hline 20. Help with finding information resources in women's health & & & .755 & .663 & & \\
\hline 21. My health professional's ability to explain things clearly & & & .625 & .747 & & \\
\hline 22. The chance to get both gynaecological and general health care here & & & .570 & .675 & & \\
\hline
\end{tabular}

Total variance $=71.16$; Cronbach's $\alpha=.97$ (22 items) 
To aid in the interpretation of these four components, Varimax rotation was performed. The rotated solution revealed the presence 24 items of four components showing a number of strong loadings (>0.3) and loading substantially on only one component (ranged 0.45-0.84). The four component solution explained a total of 60.7 percent of the variance, with Component $1=24.6 \%$, Component $2=15.3 \%$, component $3=11.1 \%$ and factor four contributing $9.75 \%$. Thus, the PQPCS scale was formed from four dimension and 24 items. The first group $(\alpha)$ included twelve items related to the attitudes and practices of the health care workers: counselling skill, respectfulness, diagnostic skill, confidentiality, adequacy and extent of clinical examination, sympathy, honesty, open heartedness, information about test and procedures, time spent for explaining women health problem, and lastly, prescribing efficiency. The second group included five items referring to management; collecting drug, monitoring, overall management, IEC material and quality of drugs. The four items in the third group focused more specifically on administrative procedure; staff availability, examining place, timeliness and punctuality of the caregiver. Three items of fourth group referred to physical facilities; toilet facilities, drinking water supply, cleanliness and external environment. It is important to be noted that items related to fees, distance, drug quality, bribe, equipment are dropped down from the final scale and at the same time items related to counselling skill, confidentiality, punctuality and physical environment are included. (A comparison of the newly develop scale items with initial 30 scale items and with Haddad's 20 item scale has been shown in the annexure.) Table A.

Table A. Final 24 scale items of perceived quality primary care service scale PQPCS was formed from four dimension and 24 items. (comparison with Slim Haddad's scale items)

\begin{tabular}{|l|l|l|}
\hline $\begin{array}{l}\text { Slim Haddad's 20 scale items for } \\
\text { measuring health service quality }\end{array}$ & $\begin{array}{l}\text { Initial 30 attributes } \\
\text { stated by lay people } \\
\text { to judge quality }\end{array}$ & $\begin{array}{l}\text { Final scale items } \\
\text { resulted after } \\
\text { factoranalysis }\end{array}$ \\
\hline $\begin{array}{l}\text { In your opinion, are the "doctors" in the } \\
\text { "hospital" capable of finding out what is } \\
\text { wrong with the patients? }\end{array}$ & $\begin{array}{l}\text { Skill in detecting } \\
\text { health problem }\end{array}$ & $\begin{array}{l}\text { Skill in detecting } \\
\text { health problem }\end{array}$ \\
\hline $\begin{array}{l}\text { In your opinion, are the drugs needed } \\
\text { thatthe "doctors" in the hospital } \\
\text { prescribe to patients... }\end{array}$ & $\begin{array}{l}\text { How good their } \\
\text { prescription }\end{array}$ & $\begin{array}{l}\text { How good their } \\
\text { prescription }\end{array}$ \\
\hline $\begin{array}{l}\text { In your opinion, patients can obtain } \\
\text { drugseasily from this hospital }\end{array}$ & $\begin{array}{l}\text { Collecting drugs } \\
\text { fromcc }\end{array}$ & $\begin{array}{l}\text { Collecting } \\
\text { drugs fromcc }\end{array}$ \\
\hline $\begin{array}{l}\text { The drugs supplied by this "hospital } \\
\text { are good }\end{array}$ & Quality of drug & X \\
\hline $\begin{array}{l}\text { The patients cared for in this hospital } \\
\text { recover good }\end{array}$ & Result of treatment & $\begin{array}{l}\text { Result of } \\
\text { treatment }\end{array}$ \\
\hline $\begin{array}{l}\text { In your opinion, the "doctors" in the } \\
\text { hospital examine their patients well }\end{array}$ & $\begin{array}{l}\text { What extent they } \\
\text { examine }\end{array}$ & $\begin{array}{l}\text { What extent } \\
\text { they examine }\end{array}$ \\
\hline $\begin{array}{l}\text { In your opinion, the "doctors" in the } \\
\text { hospital monitor their patient's } \\
\text { recovery well }\end{array}$ & Monitoring & Monitoring \\
\hline $\begin{array}{l}\text { In your opinion, the doctors in the } \\
\text { hospital are open with thepatients }\end{array}$ & Open hearted & Open hearted \\
\hline
\end{tabular}

\begin{tabular}{|c|c|c|}
\hline $\begin{array}{l}\text { In your opinion, the "doctors" in the } \\
\text { "hospital" are compassionate towards } \\
\text { the patients. }\end{array}$ & $\begin{array}{l}\text { Sympathetic/ } \\
\text { compassionate }\end{array}$ & $\begin{array}{l}\text { Sympathetic/ } \\
\text { compassionate }\end{array}$ \\
\hline $\begin{array}{l}\text { In your opinion, the "doctors" are } \\
\text { respectfultowards the patients }\end{array}$ & Respectfulness & Respectfulness \\
\hline $\begin{array}{l}\text { In your opinion, the time that the } \\
\text { "doctors" devote to their patients is } \\
\text { adequate }\end{array}$ & $\begin{array}{l}\text { Hurry during } \\
\text { examining } \\
\text { patient }\end{array}$ & $\begin{array}{l}\text { Hurry during } \\
\text { examining } \\
\text { patient }\end{array}$ \\
\hline $\begin{array}{l}\text { In your opinion, the time that the } \\
\text { "doctors" take to explain to their } \\
\text { patients about their illness is adequate }\end{array}$ & $\begin{array}{l}\text { Time spent } \\
\text { explainingtheir } \\
\text { illness }\end{array}$ & $\begin{array}{l}\text { Time spent } \\
\text { explainingtheir } \\
\text { Illness treatment }\end{array}$ \\
\hline $\begin{array}{l}\text { In your opinion, the people who work in } \\
\text { this "hospital" are honest }\end{array}$ & Honesty & Honesty \\
\hline $\begin{array}{l}\text { In your opinion, the fees that are } \\
\text { charged in this "hospital" are reasonable }\end{array}$ & $\begin{array}{l}\text { Rationality of free } \\
\text { service }\end{array}$ & $x$ \\
\hline $\begin{array}{l}\text { In your opinion, in this "hospital" } \\
\text { patients have access to credit easily! }\end{array}$ & Total expenses & $x$ \\
\hline $\begin{array}{l}\text { The distance from your home to the } \\
\text { "hospital"... is reasonable }\end{array}$ & Distance CC & $\mathrm{X}$ \\
\hline $\begin{array}{l}\text { In your opinion, the number of } \\
\text { "doctors" inthis "hospital" is adequate }\end{array}$ & $\begin{array}{l}\text { Health provider } \\
\text { available }\end{array}$ & $\begin{array}{l}\text { Health provider } \\
\text { available }\end{array}$ \\
\hline $\begin{array}{l}\text { In your opinion, the "doctors" in the } \\
\text { "hospital" are well suited to treat } \\
\text { women's diseases }\end{array}$ & $\begin{array}{l}\text { Time spent explaining } \\
\text { female patient }\end{array}$ & $\begin{array}{l}\text { Time spent } \\
\text { explaining } \\
\text { female patient }\end{array}$ \\
\hline $\begin{array}{l}\text { In your opinion, the equipment in the } \\
\text { "hospital" adequate for detecting } \\
\text { diseases }\end{array}$ & Equipment in $\mathrm{CCX}$ & $x$ \\
\hline $\begin{array}{l}\text { In your opinion, the waiting rooms, } \\
\text { examination rooms, and "hospital" } \\
\text { rooms are adequate }\end{array}$ & $\begin{array}{l}\text { Examining place } \\
\text { (areaused adequate) }\end{array}$ & $\begin{array}{l}\text { Examining } \\
\text { place (area } \\
\text { used adequate) }\end{array}$ \\
\hline $\mathrm{X}$ & Counselling skill & Counselling skill \\
\hline $\bar{X}$ & $\begin{array}{l}\text { Information on test } \\
\text { \&procedures } \sqrt{ }\end{array}$ & $\begin{array}{l}\text { Information on } \\
\text { test \& } \\
\text { procedures } \sqrt{ }\end{array}$ \\
\hline $\bar{X}$ & Confidentiality & Confidentiality \\
\hline $\bar{x}$ & Bribe & $\mathrm{X}$ \\
\hline $\bar{X}$ & $\begin{array}{l}\text { Timeliness/ } \\
\text { punctuality/ }\end{array}$ & $\begin{array}{l}\text { Timeliness/ } \\
\text { punctuality }\end{array}$ \\
\hline $\mathrm{X}$ & Staff availablev & Staff available \\
\hline $\mathrm{X}$ & Toilet facilities $\sqrt{ }$ & Toilet facilities \\
\hline $\mathrm{X}$ & $\begin{array}{l}\text { Drinking water } \\
\text { supply }\end{array}$ & $\begin{array}{l}\text { Drinking water } \\
\text { supply }\end{array}$ \\
\hline $\bar{X}$ & $\begin{array}{l}\text { External } \\
\text { environment } \sqrt{ }\end{array}$ & $\begin{array}{l}\text { External } \\
\text { environment }\end{array}$ \\
\hline
\end{tabular}

Construction of scales and subscales for measuring perceived quality

Factor analysis [Table II]

A factor analysis of the current results was performed using the Maximum Likelihood method of extraction. Bartlett's test of sphericity was significant $\left[\chi^{2} \quad(231)=18916.51, \quad \mathrm{p}<0.001\right]$, and Kaiser-Meyer-Olkin measure of sampling adequacy was 0.97 indicating that it was appropriate to use the factor analytic model on this set of data. PCA revealed the presence of three factors with eigen values greater than one which indicated that three factors gave the most interpretable solution. Using Catell's (1966) scree test, it was decided to retain three components for further investigation. An Oblimin rotation was performed since factors were expected to be correlated. The obtained pattern matrix is displayed in Table. Only 22 items with factor loadings of above 0.35 are shown. (Two items of PCSSW were dropped as they showed smaller loading $<0.3$ "help 
me scheduling my next visit", "the chance to talk with my health professionals with my clothes on"). The first factor was robust, with a high eigen value of 12.95 , and it accounted for $58.84 \%$ of the variance in the data. Factor two had an eigenvalue of 1.7 and accounted for a further $7.76 \%$ of the variance. The eigenvalues for factors three were 1.1 accounting for a further $4.6 \%$ of the total variance.

The pattern matrix revealed factor one to consist of 11 items. This factor was labelled interpersonal skill and attitude of the care provider and demonstrated a high internal consistency (chronbach's $\alpha=0.95$ ). The second factor consisted of seven items including preventive and promotive health services questions and reflected a high internal consistency (chronbach's $\alpha=0.92$ ). Factor three contained four items relating to the issues of women health and was labelled women health issues. The internal consistency of this item was also high (chronbach's $\alpha=0.86$ ). In summary, the three factors retained were interpersonal skill and attitude of the care provider, preventive and promotive health services, women health issues. These three factors were considered subscales of CC Service Satisfaction scale for Bangladeshi women amenable to measure women's related to CC services.

\section{Internal consistency}

The analysis revealed three factors; interpersonal skill and attitude of the care provider, preventive and promotive health service, women health service of CC. The CCSS was found to have an overall coefficient alpha of 0.97. Alphas of the three factors ranged from 0.86 to 0.95 (see Table).

Measuring influence of sociodemographic status, perceived service quality and satisfaction on CC services utilization

To identify aspects of perceived quality and satisfaction on the utilization status of the CC services, 960 respondents were interviewed with the newly developed tools from $12 \mathrm{CC}$ catchment areas. The mean (SD) age of the respondents was 23.4 (4.15) and almost all of them are home makers. About $95 \%$ of the respondents were Muslims and 5\% were Hindus. The average monthly expenditure of their family was 7462.92 BDT (SD 2545 BDT) that is equivalent to 95 US\$ (SD 32 US\$). Detail description of the sociodemographic characteristics are presented in Table III. Study result showed limited curative care service utilization provided by CCs was significantly associated with mother's education, age, education, occupation of father, average monthly family income, residential and cultivable land ownership. These explanatory variables also found significantly associated with the health education service delivered by the selected CCs. Limited curative care was found related to all domains of PQPCS and interpersonal skill and attitude of the care provider domain and women health issue domain of CCSS but health education revealed significant association with all domains of both PQPCS and CCSS. Maternal and child health counselling services provided by the $\mathrm{CC}$ showed significant relationship with parental characteristics along with cultivable land ownership, latrine use and availability of electricity. Counselling was also found associated with three domains (Skill and competence, Management, Administration) of PQPCS and all domains of CCSS. Collection of family planning material was not applicable for all samples. Analysing the eligible subsample data, parental age, their educational attainment, husband's occupational status, availability of electricity, all domains of both PQPCS and CCSS revealed significant relationship with family planning material collection from CC. Parental characteristics (age, education, occupation), family income, land used for residence and type of latrine showed significant association with the ANC and PNC services provided by the CCs. Three domains (Skill and competence, management, physical environment) of PQPCS and one domain (women health issue) of CCSS were also found related to ANC and PNC services [Table III].

To identify the important predictors and to control the confounding effects of other variables, five binary logistic regression models were constructed. First model (predictors for limited curative care) showed educational status of mother, father's occupation, average monthly family income, residential and cultivable land ownership increased the likelihood of curative care service utilization provided by CCs. In this study, mother's literacy (pre-primary education), their residence ownership, perceived quality related to health carer skill and competence, satisfaction related to their interpersonal skill and attitude showed increased probability of limited curative care services to be utilized. On the other hand, father's service, their solvency and land ownership, their perception related to $\mathrm{CC}$ management quality, satisfaction related to preventive and promotive health services decreased the likelihood of curative care service utilization. This study showed mothers with preprimary education $\left[\left(\chi^{2}=4.20, \mathrm{p}=0.04\right)\right.$, AOR with $95 \% \mathrm{CI}=1.89(1.03,3.53)]$ utilized the limited curative care services more than educated mothers. On the contrary, higher income families [for income group 5000-10,000 BDT $\chi^{2}=8.83, \mathrm{p}=0.003$ and AOR with $95 \% \mathrm{CI}=.37(0.19,0.71)]$ and [for 
TableIII: Univariate analysis between Sociodemographic characteristics, PQPCS, CCSS subscales with service utilization status of Community Clinic

\begin{tabular}{|c|c|c|c|c|c|c|c|c|c|c|c|c|c|c|c|}
\hline \multirow[t]{2}{*}{ characteristics } & \multicolumn{3}{|c|}{ Limited curative care } & \multicolumn{3}{|c|}{ Health education } & \multicolumn{3}{|c|}{ Counselling service(MCH) } & \multicolumn{3}{|c|}{ FP material* } & \multicolumn{3}{|c|}{ ANC \& PNC } \\
\hline & No/n (\%) & Yes/n(\%) & $\begin{array}{c}\chi^{2} \\
\text { (P value) }\end{array}$ & No/ n (\%) & Yes/n(\%) & $\begin{array}{c}\chi^{2} \\
\text { Pvalue }\end{array}$ & No/ $\mathbf{n}(\%)$ & Yes/n(\%) & $\begin{array}{c}\chi^{2} \\
\text { P value }\end{array}$ & No/n $(\%)$ & Yes/n(\%) & $\begin{array}{c}\chi^{2} \\
\text { P value }\end{array}$ & No/ $n(\%)$ & Yes/n(\%) & $\begin{array}{c}\chi^{2} \\
\text { Pvalue }\end{array}$ \\
\hline \multicolumn{16}{|l|}{ Maternal age } \\
\hline $\begin{array}{l}<20 \\
20-25\end{array}$ & $\begin{array}{r}49(35) \\
183(37)\end{array}$ & $\begin{array}{r}90(65) \\
312(63)\end{array}$ & NS & $\begin{array}{r}87(63) \\
329(67)\end{array}$ & $\begin{array}{r}52(37) \\
166(33)\end{array}$ & $\begin{array}{l}2.83 \\
(.24)\end{array}$ & $\begin{array}{l}71(51) \\
272(55)\end{array}$ & $\begin{array}{l}628(49) \\
223(45)\end{array}$ & $\left.\begin{array}{c}2.41 \\
(.29)\end{array}\right]$ & $\begin{aligned} 41(62) \\
181(54)\end{aligned}$ & $\begin{array}{r}25(38) \\
152(46)\end{array}$ & $\begin{array}{r}7.37 \\
(.025)\end{array}$ & $\begin{aligned} 904(82) \\
404(8)\end{aligned}$ & $\begin{array}{l}42(30) \\
91(18)\end{array}$ & $\begin{array}{l}20.48 \\
(.000)\end{array}$ \\
\hline \multirow{2}{*}{\multicolumn{16}{|c|}{ Maternal education }} \\
\hline & & & & & & & & & & & & & & & \\
\hline prepri & $\begin{array}{r}44(29) \\
4\end{array}$ & $110(71)$ & {$\left[\begin{array}{l}3.000) \\
(.000)\end{array}\right.$} & $88(57)$ & $66(43)$ & $(.000)$ & $88(57)$ & $66(43)$ & $\left.\begin{array}{l}1.00 \\
(.008)\end{array}\right]$ & $48(53)$ & $42(47)$ & $\begin{array}{l}0.09 \\
0.09)\end{array}$ & $95(62)$ & $59(38)$ & $\begin{array}{l}0.00 \\
(.000) \\
-10\end{array}$ \\
\hline primary & $158(35)$ & $292(65)$ & & $291(65)$ & 159 (35 & & $245(5$ & $205(4$ & & $162(5$ & $148(4$ & & $370(8$ & $80(1$ & \\
\hline \multirow{2}{*}{\multicolumn{16}{|c|}{$102(82)$}} \\
\hline & & & & & & & & & & & & & & & \\
\hline $25-30$ & $175(38)$ & $283(62)$ & $(.000)$ & $298(65)$ & $160(35)$ & $(.000)$ & $239(52)$ & $219(48)$ & $(.004)$ & $157(54)$ & & $(.002)$ & & & 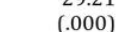 \\
\hline \multirow{2}{*}{\multicolumn{16}{|c|}{$\begin{array}{l}>30 \\
\text { Husbands education }\end{array}$}} \\
\hline & $174(60)$ & $116(40)$ & 90.45 & $259(89)$ & $31(11)$ & 98.86 & $202(70)$ & $88(30)$ & 37.14 & $51(37)$ & $88(63)$ & & $282(97)$ & & \\
\hline preprimary & $31(21)$ & $116(79)$ & $(.000)$ & $74(50)$ & $73(50)$ & $(.000)$ & $83(37)$ & $64(43)$ & $(.000)$ & $51(53)$ & $46(47)$ & $(.000)$ & $94(64)$ & $53(36)$ & $(.000)$ \\
\hline & $111(2$ & $267(7$ & & $224(5$ & $154(41$ & & $183(4$ & $195(5$ & & $153(57)$ & $116 c^{4}$ & & 284( & $94(25)$ & \\
\hline \multicolumn{16}{|l|}{$\begin{array}{l}\text { secondary } \\
\text { Occupation of husband }\end{array}$} \\
\hline $\begin{array}{l}\text { Occuppation of nuspana } \\
\text { Farmer }\end{array}$ & $92(32)$ & $197(68)$ & 8.50 & $174(60)$ & $115(40)$ & 9.44 & $161(56)$ & $128(44)$ & 22.26 & $78(48)$ & $85(52)$ & 8.25 & $216(75)$ & $73(25)$ & 14.45 \\
\hline Daily labor & $112(41)$ & $163(59)$ & $(.037)$ & $195(70)$ & $80(29)$ & $(.024)$ & $181(66)$ & & $(.000)$ & $78(48)$ & $83(52)$ & $(.04)$ & & $39(14)$ & $(.002)$ \\
\hline Service & $124(43)$ & $167(57)$ & & 201(69) & $90(30)$ & & $148(51)$ & $143(49)$ & & $118(61)$ & $77(39)$ & & $246(85)$ & $45(15)$ & \\
\hline \multirow{2}{*}{\multicolumn{16}{|c|}{ Familyincome }} \\
\hline & & & & & & & & & & & & & & & \\
\hline $5000-10000$ & $\begin{array}{r}242(20) \\
248)\end{array}$ & $\begin{array}{l}944(80) \\
394(62)\end{array}$ & $\begin{array}{r}2.46 \\
(.000)\end{array}$ & $\begin{aligned} 60(51) \\
410(65)\end{aligned}$ & $\begin{array}{r}58(49) \\
226(35)\end{array}$ & $\left.\begin{array}{l}45.91 \\
.000)\end{array}\right]$ & $\begin{array}{l}588(49) \\
35(56)\end{array}$ & $\begin{array}{l}60(51) \\
279(44)\end{array}$ & $\begin{array}{c}2.45 \\
(.29)\end{array}$ & $\begin{array}{l}48(61) \\
197(50)\end{array}$ & $\begin{array}{l}31(39) \\
199(50)\end{array}$ & $\begin{array}{c}3.43 \\
(.18)\end{array}$ & $\begin{array}{l}69(59) \\
526(83)\end{array}$ & $\begin{array}{l}410(17) \\
110(17)\end{array}$ & $\begin{array}{l}\begin{array}{l}60.16 \\
(.000)\end{array} \\
-\end{array}$ \\
\hline \multicolumn{16}{|l|}{$\begin{array}{l}>10000 \\
\text { House owne }\end{array}$} \\
\hline Rental & $17(38)$ & $28(62)$ & NS & $25(56)$ & $20(4$ & 2.90 & $22(49)$ & $23(51)$ & .86 & 9) & & 1.61 & & $17(38)$ & 12.29 \\
\hline $\begin{array}{l}\text { Own house } \\
\text { Residenceland }\end{array}$ & \multicolumn{7}{|c|}{ Residence land } & & $(.22)$ & $303(53)$ & $273(47)$ & (.28) & 758(83) & $157(17)$ & $(.000)$ \\
\hline 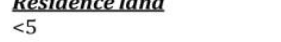 & $62(26)$ & $174(74)$ & 40.61 & 139(59) & $97(41)$ & 42.60 & $137(58)$ & & .86 & & & .55 & & $71(30)$ & 33.22 \\
\hline $5-10$ & 119 & & $(.000)$ & & & $(.000)$ & $4(54)$ & & (.65) & $124(54)$ & & (.7) & 298(83) & $60(17)$ & $(.000)$ \\
\hline \\
\hline & & & & & & & & & & & & & & & \\
\hline$<50$ decimal & $44(29)$ & 18 & $(.026)$ & $98(64)$ & & (.14) & $76(50)$ & & $(.05)$ & & & $(.37)$ & & & (.23) \\
\hline \multicolumn{16}{|l|}{$\begin{array}{l}=>50 \text { decimal } \\
\text { Type of latrine }\end{array}$} \\
\hline $\begin{array}{l}\text { Type oflactime } \\
\text { Pit type }\end{array}$ & $194(40)$ & $288(60)$ & 2.04 & $338(70)$ & $144(30)$ & 3.79 & $298(62)$ & $184(38)$ & 15.08 & $157(52)$ & $145(48)$ & nS & $433(90)$ & $49(10)$ & 41.32 \\
\hline Sanitary & $171(36)$ & $307(64)$ & (.16) & $307(64)$ & $171(36)$ & $(.05)$ & $236(49)$ & $242(51)$ & $(.000)$ & $155(52)$ & $142(48)$ & & $353(74)$ & $125(26)$ & $(.000)$ \\
\hline & & & & & & & & & & & & & & & \\
\hline No & $260(40)$ & $300(60)$ & $3.35(.075)$ & & & 1.29 & & & 19.00 & & & 15.64 & & & \\
\hline Yes & $105(34)$ & $205(66)$ & & $216(70)$ & $94(30)$ & $(.27)$ & $141(44)$ & $169(56)$ & $(.000)$ & $133(63)$ & $78(37)$ & $(.000)$ & $262(85)$ & $48(15)$ & (.14) \\
\hline Scales and subscales & \multicolumn{2}{|c|}{ Mean(SD) } & $t$ (p value) & \multicolumn{2}{|c|}{ Mean(SD) } & $t$ (p value) & \multicolumn{2}{|c|}{ Mean(SD) } & $t$ (p value) & Mean & (SD) & t (p value) & Mean & (SD) & $t$ (p value) \\
\hline & & $2213(4.41)$ & (92) & $35(4.77)$ & $2289(4.34)$ & $-825(000)$ & $1938(480)$ & $23.44(366)$ & $-1487(000)$ & $2062(4.71)$ & $2203(462)$ & & $2085(485)$ & & $-5(000)$ \\
\hline (nime or & & & & & & & & & & & & 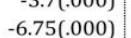 & & & $5.03(.000)$ \\
\hline 4 iten & $3(1.78)$ & $5.73(1.10)$ & $5.76(.000)$ & $8(1.59)$ & $0(.98)$ & (.000) & $5.64(1.07)$ & $6.35(1.70)$ & -7.58(.000) & $5.57(.93)$ & $5.90(1.35)$ & $-3.44(.001)$ & $5.98(1.50)$ & $5.85(1.04)$ & $1.36(.17)$ \\
\hline 3 item & $4.88(1.72)$ & $4.66(1.41)$ & $2.05(.04)$ & $89(1.61)$ & $4.44(1.32)$ & $65(.000)$ & $4.66(1.49)$ & $4.85(1.59)$ & $-1.86(.06)$ & $4.41(1.41)$ & $5(1.51)$ & $-4.90(.000)$ & $4.86(1.58)$ & $4.22(1.22)$ & $5.95(.000)$ \\
\hline & & & & & & & & & & & & & & & \\
\hline 11 item & $04(7.58)$ & 22 & 0) & $20(6.6)-5)$ & & $-5.39(.00$ & 19.41(5.90) & 2 & $-14.07(.000)$ & $20.39(6.66)$ & $23.42(7.08)$ & $-5.39(.000)$ & $21.29(6.62)$ & $25.80(8.27)$ & $-6.74(.000)$ \\
\hline 7 item & $.28(4.11)$ & $17(3.54)$ & $.43(\mathrm{~ns})$ & $10.99(3.82)$ & $.67(3.63)$ & $-2.68(.008)$ & $9.75(2.95)$ & $13.05(3.88)$ & $-14.53(.000)$ & $10.34(3.44)$ & $11.71(3.5)$ & $-4.84(.000)$ & $11.18(3.72)$ & $11.35(3.99)$ & $-.51(.61)$ \\
\hline 4 item & $9.30(2.82)$ & $10.15(2.37)$ & $4.85(.000)$ & $9.48(2.58)$ & $10.55(2.43)$ & $-6.31(.000)$ & $8.95(2.38)$ & $10.93(2.40)$ & $-12.78(.000)$ & $9.24(2.53)$ & $10.48(2.38)$ & $-6.19(.000)$ & $9.76(2.51)$ & $10.13(2.87)$ & $-1.57(.12)$ \\
\hline
\end{tabular}


TableIV: Binary logistic regression models for identifying significant predictors of Community Clinic service utilization status

\begin{tabular}{|c|c|c|c|c|c|c|c|c|c|}
\hline $\begin{array}{l}\text { Predictors } \\
\end{array}$ & $\begin{array}{r}\text { Model 1:General } \\
\text { Health/Limited } \\
\text { curative care } \\
\chi^{2}(\mathrm{p} \text { value }) \\
{[\text { AOR with }(95 \% \mathrm{CI})]}\end{array}$ & Predictors & $\begin{array}{r}\text { Model2: Health } \\
\text { information } \\
\chi^{2}(\mathrm{p} \text { value) } \\
\text { [AOR with }(95 \% \mathrm{CI})]\end{array}$ & Predictors & $\begin{array}{r}\begin{array}{r}\text { Model3: Counselling } \\
\text { (MCH) }\end{array} \\
\chi^{2}(\mathrm{p} \mathrm{value}) \\
{[\mathrm{AOR} \text { with }(95 \% \mathrm{CI})]}\end{array}$ & Predictors & $\begin{array}{r}\text { Model4: Collection of } \\
\text { FP material } \\
\chi^{2}(\mathrm{p} \text { value }) \\
{[\mathrm{AOR} \text { with }(95 \% \mathrm{CI})]}\end{array}$ & Predictors & $\begin{array}{r}\text { Model5: ANC and } \\
\text { PNC services } \\
\chi^{2}(\mathrm{p} \text { value }) \\
\text { [AOR with }(95 \% \mathrm{CI})]\end{array}$ \\
\hline $\begin{array}{l}\text { Mothers with preprimary } \\
\text { education }\end{array}$ & $\begin{array}{r}4.20(.04) \\
{[1.89(1.03,3.53)]}\end{array}$ & $\begin{array}{l}\text { Husband's } \\
\text { preprimary } \\
\text { education }\end{array}$ & $\begin{array}{r}8.41(.004) \\
{[3.03(1.43,6.41)]}\end{array}$ & $\begin{array}{l}\text { Husband's primary } \\
\text { education }\end{array}$ & $\begin{array}{r}4.68(.03) \\
{[1.81(1.06,3.10)]}\end{array}$ & $\begin{array}{l}\text { Average monthly } \\
\text { family income } \\
5000-10000\end{array}$ & $\begin{array}{r}10.93(.001) \\
{[3.64(1.69,7.82)]}\end{array}$ & $\begin{array}{l}\text { Mothers age more } \\
\text { than } 25 \text { years }\end{array}$ & $\begin{array}{r}4.11(.043) \\
{[.330(.11, .96)]}\end{array}$ \\
\hline $\begin{array}{l}\text { Husband occupation } \\
\text { [Service] }\end{array}$ & $\begin{array}{r}4.76(.029) \\
{[.56(.33, .94)]}\end{array}$ & $\begin{array}{l}\text { Husband's } \\
\text { primary } \\
\text { education }\end{array}$ & $\begin{array}{r}9.10(.003) \\
{[2.77(1.43,5.38)]}\end{array}$ & $\begin{array}{l}\text { Husband's } \\
\text { secondary } \\
\text { education }\end{array}$ & $\begin{array}{r}5.23(.022) \\
{[2.28(1.13,4.60)]}\end{array}$ & $\begin{array}{l}\text { Average monthly } \\
\text { family income } \\
>10000\end{array}$ & $\begin{array}{r}3.93(.047) \\
{[2.59(1.01,6.65)]}\end{array}$ & $\begin{array}{l}\text { Mothers completed } \\
\text { secondary education }\end{array}$ & $\begin{array}{r}5.51(.019) \\
{[3.40(1.22,9.46)]}\end{array}$ \\
\hline $\begin{array}{l}\text { Average monthly family } \\
\text { income } 5000-10000\end{array}$ & $\begin{array}{r}8.83(.003) \\
{[.37(.19, .71)]}\end{array}$ & $\begin{array}{l}\text { Husband's } \\
\text { secondary } \\
\text { education }\end{array}$ & $\begin{array}{r}9.18(.002) \\
{[3.56(1.57,8.09)]}\end{array}$ & $\begin{array}{l}\text { Perceived quality } \\
\text { related to Skill and } \\
\text { competence }\end{array}$ & $\begin{array}{r}38.87(.000) \\
{[1.24(1.16,1.32)]}\end{array}$ & $\begin{array}{l}\text { Sanitary latrine } \\
\text { users }\end{array}$ & $\begin{array}{r}5.16(.023) \\
{[1.78(1.08,2.94)]}\end{array}$ & $\begin{array}{l}\text { Husband's } \\
\text { preprimary } \\
\text { education }\end{array}$ & $\begin{array}{r}12.60(.000) \\
{[5.93(2.22,15.82)]}\end{array}$ \\
\hline $\begin{array}{l}\text { Average monthly family } \\
\text { income }>10000\end{array}$ & $\begin{array}{r}5.02(.025) \\
{[.40(.18, .89)]} \\
\end{array}$ & $\begin{array}{l}\text { Average } \\
\text { monthly family } \\
\text { income }>10000\end{array}$ & $\begin{array}{r}4.47(.034) \\
{[.40(.17, .94)]}\end{array}$ & $\begin{array}{l}\text { Perceived quality } \\
\text { related to } \\
\text { management }\end{array}$ & $\begin{array}{r}10.97(.001) \\
{[.84(.76, .93)]}\end{array}$ & $\begin{array}{l}\text { Perceived quality } \\
\text { related to } \\
\text { management }\end{array}$ & $\begin{array}{r}6.22(.013) \\
{[1.17(1.03,1.32)]}\end{array}$ & $\begin{array}{l}\text { Husband's primary } \\
\text { education }\end{array}$ & $\begin{array}{r}11.57(.001) \\
{[4.87(1.96,12.12)]}\end{array}$ \\
\hline Own houses & $\begin{array}{r}7.67(.006) \\
3.23(1.41,7.40)\end{array}$ & $\begin{array}{l}\text { Perceived } \\
\text { quality related } \\
\text { to Skill and } \\
\text { competence }\end{array}$ & $\begin{array}{r}24.00(.000) \\
{[1.21(1.12,1.30)]}\end{array}$ & $\begin{array}{l}\text { Perceived quality } \\
\text { related to } \\
\text { administration }\end{array}$ & $\begin{array}{r}27.49(.000) \\
{[1.61(1.35,1,93)]}\end{array}$ & $\begin{array}{l}\text { Satisfaction } \\
\text { related to women } \\
\text { health issue }\end{array}$ & $\begin{array}{r}3.57(.05) \\
{[1.16(1.00,1.36)]}\end{array}$ & $\begin{array}{l}\text { Cultivable land }=>50 \\
\text { decimal }\end{array}$ & $\begin{array}{r}5.01(.025) \\
{[.48(.25, .91)]}\end{array}$ \\
\hline $\begin{array}{l}\text { Residential land 5- } \\
\text { 10decimal }\end{array}$ & $\begin{array}{r}5.51(.019) \\
{[.56(.35, .91)]}\end{array}$ & $\begin{array}{l}\text { Perceived } \\
\text { quality related } \\
\text { to management }\end{array}$ & $\begin{array}{r}37.10(.000) \\
{[.69(.61, .78)]}\end{array}$ & $\begin{array}{l}\text { Satisfaction related } \\
\text { to interpersonal } \\
\text { skill and attitude of } \\
\text { the care provider }\end{array}$ & $\begin{array}{r}7.42(.006) \\
{[1.08(1.02 .1 .14)]}\end{array}$ & & & $\begin{array}{l}\text { Perceived quality } \\
\text { related to } \\
\text { management }\end{array}$ & $\begin{array}{r}10.59(.001) \\
{[.79(.68, .91)]}\end{array}$ \\
\hline $\begin{array}{l}\text { Residential land >10 } \\
\text { decimal }\end{array}$ & $\begin{array}{r}6.70(.010) \\
.50(.29, .84)\end{array}$ & $\begin{array}{l}\text { Perceived } \\
\text { quality related } \\
\text { to physical } \\
\text { environment }\end{array}$ & $\begin{array}{r}9.27(.002) \\
{[.781(.67, .92)]}\end{array}$ & $\begin{array}{l}\text { Satisfaction related } \\
\text { to preventive and } \\
\text { promotive health } \\
\text { services }\end{array}$ & $\begin{array}{r}4.23(.040) \\
{[1.09(1.01,1.19)]}\end{array}$ & & & $\begin{array}{l}\text { Perceived quality } \\
\text { related to } \\
\text { administration }\end{array}$ & $\begin{array}{r}4.87(.027) \\
{[.77(.61, .97)]}\end{array}$ \\
\hline $\begin{array}{l}\text { Perceived quality related } \\
\text { to Skill and competence }\end{array}$ & $\begin{array}{r}16.90(.000) \\
1.14(1.07,1.22)\end{array}$ & & & & & & & $\begin{array}{l}\text { Satisfaction related to } \\
\text { preventive and } \\
\text { promotive health } \\
\text { services }\end{array}$ & $\begin{array}{r}3.74(.053) \\
{[.90(.81,1.00)]}\end{array}$ \\
\hline $\begin{array}{l}\text { Perceived quality related } \\
\text { to management }\end{array}$ & $\begin{array}{l}34.45(.000) \\
.73(.65, .81)\end{array}$ & & & & & & & & \\
\hline $\begin{array}{l}\text { Satisfaction related to } \\
\text { interpersonal skill and } \\
\text { attitude of the care } \\
\text { provider }\end{array}$ & $\begin{array}{r}7.07(.008) \\
1.081(1.02,1.15)\end{array}$ & & & & & & & & \\
\hline $\begin{array}{l}\text { Satisfaction related to } \\
\text { preventive and promotive } \\
\text { health services }\end{array}$ & $\begin{array}{r}5.10(.024) \\
.90(.82, .99)\end{array}$ & & & & & & & & \\
\hline $\begin{array}{l}\text { Cox \& Snell/Nagelkerke R2 } \\
\text { ROC ( } 95 \% \mathrm{CI})\end{array}$ & $\begin{array}{r}.36 / .49 \\
.87(.85, .90)\end{array}$ & & $\begin{array}{r}.37 / .52 \\
.88(.86, .90)\end{array}$ & & $\begin{array}{r}.35 / .47 \\
.85(.83, .88)\end{array}$ & & $\begin{array}{r}.31 / .41 \\
.83(.79, .86)\end{array}$ & & $\begin{array}{r}.29 / .48 \\
.86(.83, .9)\end{array}$ \\
\hline
\end{tabular}


income group above $10,000 \mathrm{BDT} \chi^{2}=5.02, \mathrm{p}=0.025$ and $\mathrm{AOR}$ with $95 \% \mathrm{CI}=0.40(0.18,0.89)]$ and families having cultivable lands [for 5-10 decimal group $\chi^{2}=5.51, \mathrm{p}=0.19$, and AOR with $95 \%$ $\mathrm{CI}=0.56(0.35,0.91)]$ and [for $>10$ decimal group $\chi^{2}=6.70, \mathrm{p}=0.010$, and AOR with $95 \% \mathrm{CI}=0.50$ $(0.29,0.84)]$ utilized the limited curative care services less than their poorer and landless counterpart. The same relationship was observed in case of health education and ANC and PNC services. Perceptions concerning skill and competence of the health care provider $\left[\chi^{2}=16.90\right.$, $\mathrm{p}=0.000$ and AOR with $95 \% \mathrm{CI}=1.14,(1.07,1.22)]$ and satisfaction indicating interpersonal communication and attitude of the care provider $\left[\chi^{2}=7.07, p=0.008\right.$ and AOR with 95\% CI $=1.08$, $(1.02,1.15)]$ were found significant predictors for limited curative care service utilization of CC.

Second model (predictors for health information) revealed, husband's education and perceived quality related to health carer's skill and competence found significantly increased the chance of health-education service utilization delivered by the selected CCs. On the contrary high income, perceived quality related to management, perceived quality related to physical environment decreased the chance to seek this service. Women who lived in their own residence used the health education service more frequently than those who lived in a rental house $\left[\chi^{2}=24.00, p=0.000\right.$ and AOR with $95 \% \mathrm{CI}=1.21,(1.12,1.30)]$. Limited curative care was found related to two domains of PQPCS and first and third domain of CCSS whereas health education revealed significant association with all domains of PQPCS except administrative quality domain but not related with any of the CCSS subscales.

Third model (predictors for maternal and child health counselling) indicated husbands educational attainment, perception referring to skill and competence of the care provider (PQPCS first domain), administration (domain 3 of PQPCS), satisfaction indicating interpersonal skill and attitude, preventive and promotive health enhanced the likelihood of getting maternal and child care counselling services whereas perceived quality related to management decreased the possibility of getting this service. Permanent residents used the maternal and child health services more frequently than those who lived in a rental house $\left[\chi^{2}=27.49, p=0.000\right.$ and AOR with $95 \%$ CI 1.61, $(1.35,1.93)]$

Model four (predictors for family planning) presented higher income status, families having good sanitation, perception referring to better management of CCs and satisfaction addressing women health related issues raised the probability of obtaining family planning material from CCs.

Lastly, in model five (predictors for ANC and PNC), maternal age ( $>25$ years), higher education of spouses, families having less cultivable land, showed elevated chance of ANC and PNC service utilization, while lower utilization of this service was subjected to perceived quality related to management, administration, and satisfaction related to preventive and promotive health services. [Table IV]

\section{Discussion}

Relying on the existing literature reviewed, this study is assumed to be a cogent attempt to assess the role of consumer's perception of quality and satisfaction on CCs service utilization status. The primary challenges we met were to construct appropriate tools for measuring these two psychometric issues which needed to be sensitive as well as specific in a primary care setting. Accordingly, researchers constructed a 24 item PQPCS scale that included four unique domains; perception referring to skill and competence of the care provider, management quality, administrative adequacy and physical environment of CCs. The detail of the scale components and the validity issues have been discussed in earlier section of this article. The 22 items CCSS scale was constructed from 24 items PCSSW by Scholle and colleagues, 2004. In this study CCSS items were clustered in three domains; interpersonal skill and attitude of the care provider, preventive and promotive health and women health related issues.

CCs are one stop service centres which were set to deliver all of primary health care in their catchment areas. This study revealed that poverty, women education, occupation and education of the husband, landownership significantly alter the likelihood of service utilization status. Perception referring skill and competence of the care provider and satisfaction relating interpersonal skill and attitude of the care provider and in some occasions, perception regarding management and administration, satisfaction indicating preventive and promotive health and women health related issues played significant role on $\mathrm{CC}$ service utilization. Stratified data also showed that utilization varied significantly among the selected areas. The variation of skill and competency of health worker, physical environment of the settings, socio demographic diversity might explain this variation

The overall services of CC depend not only on skill and coordination of these personnel but also on 
regular drug and equipment supplies, training, monitoring and support from higher authorities. The process used to identify the scale content is inductive, and is designed to focus on the concerns and visions of the lay people, which will obviously differ from the concept of quality held by researchers, health care authorities and providers. The unexplained variability found in these models, might also be due to the contributions of providers' perception and satisfaction related to the services they are providing.

Another limitation of the study could be that only women having children aged two years were included in this study; might limit generalization to the population. In this study, majority of patients were found satisfied, might reflect a low expectation level owing to their lifelong experience of spending a short time with health care providers. This study showed that the perceived technical quality of care for the client plays a lesser role in affecting utilization than the interpersonal nature of care.

Conclusion: PQPCS and CCSS scales for measuring perception and satisfaction were developed and validated complying adequate methodological issues. This study confirm findings in developing countries that the perception and judgement of quality are highly individualistic and dynamic, in the sense that the criteria or elements used for judging quality change with time and context. Apart from socioeconomic characteristics, perceptions referring skill and competence, management and administrative qualities of the $\mathrm{CCs}$, satisfaction indicating interpersonal skill and attitude of the care provider, health education and women health related issues presented significant influences on CC service utilization.

Competing interests

Researcher declares no competing interest.

\section{Acknowledgements}

We acknowledge Directorate General of Health Services and Bangladesh Medical Research Council for their institutional and administrative support.

\section{References}

1. Bangladesh health bulletin 2013 - Health, population and nutrition sector development program. Management Information System. Mohakhali, Dhaka1212. 2014 Feb. chapter 4, primary health care. [Document on the internet]. hpnconsortium.org/ admin/essential/HB_2013_final_-_Full_version_1 March14.pdf. Page 29.

2. Normand C, Iftekar MH, Rahman SA. Assessment of the CCs: effects on service delivery, quality and utilization of services. Health System
Development/WP/12/02. http://r4d.dfid.gov.uk/PDF /Outputs/HealthSysDev_KP/bang_comm_clinics_we b_version.pdf

3. WHO, Bangladesh - Health System in Bangladesh. Last update on:10 September 2010 www.whoban.org/en/Section25.htm.

4. Health needs and health services in rural Ghana. IDS Health Group. Soc Sci Med A.1981 Jul;15(4):397517.

5. Chabot HT, Bremmers J. Government health services versus community: conflict or harmony. Soc Sci Med. 1988; 26 (9): 957-62.

6. Sarker S, Islam Z, Routh S, Saifi RA, Begum HA, Nasim SMA et al. Operations research on ESP delivery and CCs in Bangladesh: transition plan on shift from outreach to CC-based service-delivery system; a study of perspectives of stakeholders / edited by M Shamsul Islam Khan. 2001. vi, 36 p. (ICDDR,B working paper no. 146 ).

7. Andaleeb SS. Public and private hospitals in Bangladesh: service quality and predictors of hospital choice. Oxford Journals:Health Policy Plan. 2000; 15 (1): 95-102

8. Pan X, Dib HH, Wang X, Zhang H. Service utilization in community health centers in China: a comparison analysis with local hospitals. BMC Health Serv Res. 2006 Aug;3;6:93.

9. Acharya LB, Cleland J. Maternal and child health services in rural Nepal: does access or quality matter more? Health Policy Plan. 2000 Jun;15(2):223-29.

10. Cockcroft A, Milne D and Anderson N. Bangladesh Health and Population Sector Program 19982003; The third service delivery survey 2003; Final report. CIET Canada and Ministry of Health and Family Welfare, Government of Bangladesh. Project report, Dhaka. 2004 March.; PR-BD-ban3-04.

11. Routh S and Khuda B. An Economic Appraisal of Alternative Strategies for Delivery of MCH-FP Services in Urban Dhaka, Bangladesh: International Centre for Diarrhoeal Disease Research, Bangladesh, Operations Research Project Working Paper No. 154. ICDDR,B Working Paper No. 120; 1999. URL:http://www.icddrb.org

12. Susman JL. Editorial; Assessing consumer expectations and patient satisfaction, "Passing Fad, Mission Impossible" or 'Just What the Doctor Ordered'? Archives of Family Medicine. 1994; (3): 945-46.

13. Ross CK, Steward CA, Sinacore JM. The importance of patient preferences in the measurement of health care satisfaction. Med Care. 1993; 31 (12): 1138-49.

14. Ager A, Pepper K. Patterns of health service utilization and perceptions of needs and services in rural Orissa. Health Policy Plan 2005; 20 (3): 176-84.

15. Choi KS, Cho WH, Lee S, Lee H, Kim C. The relationships among quality, value, satisfaction and behavioral intention in health care provider choice: a South Korean study. J Bus Res 2004; 5: 913-21.

16. Baltussen RMPM, Ye Y, Haddad S, Sauerborn RS Perceived quality of care of primary health services in Burkina Faso. Health Policy Plan. 2002; 17: 42-48. 
17. Rao KD, Peters DH, Bandeen-Roche K. 2006. Toward patient-centered health services in India- a scale to measure patient perceptions of quality. International Journal for Quality in Health Care. 2006; 18 (6) :414-21.

18. Haddad S, Potvin L, Roberge D, Pineault R, Remondin M. Patient perception of quality following a visit to a doctor in a primary care unit. Fam Pract. 2000; 17: 21-29.

19. Cleary PD. Satisfaction may not suffice! Int J Technol Assess Health Care. 1998; 14: 35-37.

20. Duong DV, Binns CW, Lee AH, Hipgrave DB. Measuring client-perceived quality of maternity services in rural Vietnam. Int $\mathrm{J}$ Qual Health Care 2004; 6: 447-52.

21. Haddad S, Fournier P, Potvin L. Measuring lay people's perceptions of the quality of primary health care services in developing countries. Validation of a 20-item scale International journal for Quality in Health Care 1998; 10(2): 93-104.

22. Nteta TP, Mokgatle-Nthabu M, Oguntibeju OO Utilization of the Primary Health Care Services in the Tshwane Region of Gauteng Province, South Africa. PLoS One. 2010; 5(11): e13909

23. Babar T, Shaikh and Hatcher J. Health seeking behaviour and health service utilization in Pakistan: challenging the policy makers, Journal of Public Health. 2004; 27(1): 49-54 doi:10.1093/pubmed/ fdh207.

24. Turkson PK. Perceived Quality Of Healthcare Delivery In A Rural District Of Ghana. Ghana Medical Journal. 2009; 43(2): 65-70. 